\title{
The Qur'ān and Its Biblical Subtext, by Gabriel Said Reynolds
}

Routledge Studies in the Qur'ān | New York: Routledge, 20 Io | xii + 304 pages | ISBN: 978-0-4I 5-77893-o (hardback) $£ 80.00$

When the words Qur'an and reception history are combined in the same sentence, the subject is typically

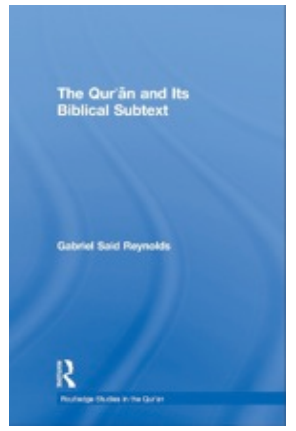
tafsir, i.e., the body of commentary literature on the Qurān produced by Muslim intellectuals in many parts of the world from, roughly, the eighth century of the Common Era to the present. In the work of scholars such as Gabriel Said Reynolds (and, in the interest of full disclosure, the author of this review), tafsir represents only one dimension of the Qur'ān's relationship to reception history—and a fairly obvious dimension at that. Less obvious at the present moment in the scholarly study of the Qur'ān is the sense in which the Qur'ān must itself be viewed as a signifi- 
cant link in the reception history of the products and processes of the Near Eastern religious imagination. Indeed, close reading of the Qur'ann in light of what Reynolds has chosen to call its "biblical subtext" shows that it is fully cognizant of a broad spectrum of the traditions that descended, as it were, from oral circulation to literary expression throughout the Ancient to Late Ancient Eastern Mediterranean and Red Sea Basin.

Even when reduced to writing, the textual remains of these traditions long resisted static codification. Texts inspire continual conversations; such conversations provoke, in turn, creative scribal redaction and revision. Canonicity comes late to this process and, even when it arrives, is not necessarily quick to preserve the text in amber. The will-to-power that privileges a particular iteration of a text and proclaims it authentic and immutable presupposes social institutions that stand to benefit from controlling textual interpretation. The first step in asserting such control is to authorize a particular version of a text-indeed, the very wording of a particular version — and, thereby, place limits upon its potential to evolve. Well before the rise of Islam in the seventh century of the Common Era, sectarian elites among Christians and Jews had established institutions to promulgate scriptural canons and enforce their textual boundaries. But what fell outside the bounds that they had themselves prescribed was, by definition, beyond their control. Moreover, what fell within canonical boundaries could only be controlled insofar as those textual borders could be effectively policed.

When Muhammad began his prophetic career, modern notions of intellectual property had not been invented and, as biblical scholars such as Michael Fishbane, Benjamin Sommers, and Richard Hays have shown persuasively, Near Eastern prophets could not be expected to heed claims to canonical jurisdiction anyway: through various modes of rhetorical appropriation, they freely trespassed the bounds of the texts which inspired them to declaim their messages. Indeed, one could justifiably regard such trespassing as the exercise of prophetic prerogative. As viewed by Reynolds and likeminded scholars, the Qur'ann is both heir to this prerogative and evidence that Muhammad (whether understood as God's Messenger by believers or the Qur'ān's author by skeptics) was an active practitioner of well-established prophetic arts.

Among these arts is the homily, and it is the homiletic voice of the Qur'ān that Reynolds's study recovers for the reader in what is a work of thorough, even-handed, and consummate scholarship. I choose the word "recovers" in this context quite deliberately; for a reading of the Qur'ān informed by the 
principles of rhetorical criticism exposes its homiletic voice as a matter of course. But the Qur'ān is rarely read by scholars in this manner. Indeed, the Qur'ān is rarely read by scholars at all without constant recourse to tafsir, or the commentary tradition. Consequently, the text is read through the eyes of medieval Muslim intellectuals who were the pillars of social institutions that stood to benefit from limits placed upon the ways in which the text could be allowed to mean: as Reynolds puts it in the book's third chapter, tafsir was the literary genre which Muslims employed "to claim the Qur'ān as their own" (20I).

Reynolds does not wait until the third chapter, however, to express his frustration with the prevailing methods of the field; instead, he opens the book with a chapter entitled "The crisis of Qur'ān." What he describes in this chapter is not, in my view, a crisis but something more akin to intellectual inertia brought about by deep confusion. The confusion lies in scholarly attachment to a form of circular reasoning whereby post-Qur'ānic literary sources that purport to interpret the Qur'ān by reference to events alleged to have occurred in the life of Muhammad (the sira literature) are relied upon to establish a chronological order for chapters or sections or individual verses of the Qur'ān itself. On the surface, such a method appears to be perfectly reasonable, particularly in light of the scarcity of evidence for the Prophet's life in the pages of the Qur'an combined with the lack of contemporaneous evidentiary attestation of the Prophet's life from sources independent of the primitive Muslim community. The reasonableness of this approach diminishes, however, when, upon close inspection of the sira literature, one discovers that it was generated by a desire on the part of Muslims to find traces of the life of the Prophet in the holy book. To then rely upon such literature to supply the missing information introduces a fatal circularity to this approach. The sira literature is best understood as an admission on the part of the post-Prophetic community that the Qur'ān tells us very little about Muhammad.

Unwilling to ride the Qur'ān-siraltafsir-Qur'ān merry-go-round, and following in the footsteps of John Wansbrough, Reynolds claims that his enterprise is not historical but literary. We shall return to the merits of this distinction at the close of this review.

The real meat of the book is chapter two: "Qur'ānic Case Studies." There are thirteen case studies in all and in each and every study Reynolds displays his prodigious linguistic skills (he appears to be perfectly at ease in at least six classical and four modern languages) and broad knowledge of the litera- 
ture which has preserved versions of the traditions that the homiletic Qur'ān chooses for its "lectionary." And "lectionary" is really what Reynolds intends by the phrase "biblical subtext." He does not mean a text from the Bible that the Qur'ānic homilist wishes to conceal from his audience but, rather, a variety of texts drawn from traditional biblical or para-biblical materials with which the Qur'annic homilist expects his audience to be familiar. Consequently, the Qur'ān is not troubled to repeat its subject texts verbatim but merely alludes to them in the course of delivering new "readings." The burden of the Qur'ān's homiletic readings is prophetic in the sense that they admonish the listener to conform to divine expectations of righteousness and to be assured that God will punish the wicked.

Each case study is composed of three main sections: (I) the Qur'annic account of the tradition in question - presumably culled from the "lectionary" which the Qur'ānic homilist shared with his audience, (2) the difficulties which several classical commentators encountered when they attempted to explain the Qur'ānic account without reference to the Qur'ānic homilist's "lectionary," and (3) Reynolds's reclamation of the specific text to which the Qur'ānic account arguably alludes. By means of this textual salvage operation, Reynolds demonstrates in convincing fashion how access to the Qur'ānic homilist's "lectionary" dispels the classical commentators' confusions. In addition, it undermines the cogency of accusations that have persisted in Orientalist circles for centuries that the Qur'ann is itself confused about aspects of biblical tradition (see, e.g., case study nine on the nativity of the mother of Jesus). It is not the Qur'ānic homilist that is confused but those Orientalists who, like the authors of classical tafsir, lacked access to the "lectionary" that the Qur'ānic homilist shared with its original audience.

Any reference to the Qur'an's original audience raises the vexed question of a literary versus an historical approach to the holy book. Despite Professor Reynolds's protests that his study is a "purely" literary (i.e., nonhistorical) exercise, no adequate literary approach to the Qur'ann or any document preserved from the past can avoid broaching historical implications. Textual meaning is context-dependent and every text inhabits multiple contexts at once: the original context to which its rhetoric is pitched and the contexts of any of its subsequent readers. At the very least, The Qur'ann and Its Biblical Subtext deals a fatal blow to the traditional narrative of Islamic origins. That narrative, produced by Muslim intellectuals over a two- to threecentury period following the death of the Prophet Muhammad, depicts the pre-Islamic Arabian Peninsula as a cultural backwater and its inhabitants as a 
primitive people enshrouded in ignorance, hopelessly devoted to pagan practices and shrines. Ignorance, pagan practices and shrines were undoubtedly present, but, as Reynolds's "non-historical” approach to the Qur'ān demonstrates most admirably, the latter two faced stiff competition from a wide variety of indigenous and imported religious innovations, including several versions of Christianity and Judaism, as well as Iranian Gnostic and prophetic traditions.

Technical quarrels aside, Professor Reynolds's book is a triumph of meticulous scholarship. It is an irresistible force on a collision course with what has been, heretofore, an immovable object: the scholarly default mode of interpreting the Qurān through medieval tafsir. Indeed, with this book, Gabriel Said Reynolds debuts as a major figure in the future of Qurānic studies and, ironically perhaps, in the future of tafsir. In light of Reynolds's work, it is difficult to imagine how interpreters of the Qur'ān-whether Muslim or non-Muslim-might justify continued reliance upon the medieval commentary tradition to discover what the Qurāan may have meant to its original audience. Had the medieval commentators possessed the tools of literary-historical excavation later invented by modern scholars of literature (and skillfully employed by Professor Reynolds), would they not have used them? Reynolds has laid the foundation for a tafsir of the future-if only future mufassirun can overcome centuries of scholarly inertia to embrace his methods.

As for Medievalists who may fear that Reynolds's scholarship will consign the great commentaries of the classical period to the ash-heap of history, I would suggest that they have mistaken the true value of that magnificent body of literature: for without it, scholars would be completely in the dark as to what the Qur'ān meant to its medieval audience. Re-discovering that audience through classical tafsir is the task to which Medievalists should apply their considerable talents - and not continue to expect medieval literature to provide insights into the early Islamic movement that it is in no position to deliver.

In closing, I would respectfully disagree with Professor Reynolds's assertion that the present state of Qur'ānic Studies is one of "crisis." Such a judgment is, regrettably, premature. May his book precipitate such a crisis, and may that crisis catapult the study of the Qurān into the twenty-first century. 